\title{
Dating Choices of High School Students
}

\author{
Sally L. Hansen \\ The Family Coordinator, Vol. 26, No. 2. (Apr., 1977), pp. 133-138.
}

Stable URL:

http://links.jstor.org/sici?sici=0014-7214\%28197704\%2926\%3A2\%3C133\%3ADCOHSS\%3E2.0.CO\%3B2-P

The Family Coordinator is currently published by National Council on Family Relations.

Your use of the JSTOR archive indicates your acceptance of JSTOR's Terms and Conditions of Use, available at

http://www.jstor.org/about/terms.html. JSTOR's Terms and Conditions of Use provides, in part, that unless you have obtained prior permission, you may not download an entire issue of a journal or multiple copies of articles, and you may use content in the JSTOR archive only for your personal, non-commercial use.

Please contact the publisher regarding any further use of this work. Publisher contact information may be obtained at http://www.jstor.org/journals/NCFR.html.

Each copy of any part of a JSTOR transmission must contain the same copyright notice that appears on the screen or printed page of such transmission.

The JSTOR Archive is a trusted digital repository providing for long-term preservation and access to leading academic journals and scholarly literature from around the world. The Archive is supported by libraries, scholarly societies, publishers, and foundations. It is an initiative of JSTOR, a not-for-profit organization with a mission to help the scholarly community take advantage of advances in technology. For more information regarding JSTOR, please contact support@ jstor.org. 


\title{
Dating Choices of High School Students*
}

\author{
SALLY L. HANSEN**
}

\begin{abstract}
Dating is experienced by most adolescents in our society as a prelude to mate selection. Three hundred and fifty-four white and black youth were studied to measure their dating-mating choices. Implications for teachers and practitioners, based on racial and gender differences, as well as perceived peer group influences are discussed.
\end{abstract}

Dating, whether for recreation, socialization, status, or courtship, emerged in our society only about fifty years ago and is experienced in some degree by most adolescents. With a few isolated exceptions, dating has replaced all other institutions for mate selection in our society.

Scholars have undertaken studies on the theory of mate selection, particularly the influence of cultural factors such as parental influence, religious training, socio-economic status, as well as age, race and gender.

Before one can answer the question of who marries whom and why, it is necessary to also look at the dynamics of what characteristics are important in a date, since dating is the prelude to mate selection. Forty years ago, Waller (1937) undertook a study of the dating patterns of college students and developed the hypothesis that for both men and women, dating choices were based on a prestige rating scheme which he called the "datingrating" system. This system, he claimed, was highly competitive and materialistic with more value being placed on external variables (owning a car, plenty of money, appropriate dress) than on internal values (intelligence,

\footnotetext{
"This article is based on a portion of the author's research for her doctoral dissertation, "Dating-Mating Choices As Related to The Self-Concept of Adolescents," December, 1974, Department of Home and Famlly Life, School of Home Economics, Florida State Unlversity. (Library Reference Number SOC-HQ-555-F5-H36)

* Sally L. Hansen is Assistant Professor, Home and Family Life-Home Economics Education, School of Home Economics, Florida State University, Tallahassee, Florida 32306.
}

dependability, consideration). The idea of prestige rating was retested in the 1950's by Smith (1952) and Blood (1963) who found some support for Waller's findings, but concluded that personality factors were more important than prestige factors in dating and mate selection.

Other frameworks for analyzing dating behavior have evolved since Waller's ratingdating theory. Skipper and Nass (1966) viewed dating as purposive behavior with four functions: (a) dating as a form of recreation, (b) dating as a form of socialization, (c) dating as a means of status grading and status achievement, (d) dating as a form of courtship. In their study they found the girls' primary motivation in dating was courtship and the males' motivation was recreation. Coombs and Kenkel (1966) found marked differences between dating aspirations of males and females. Females had more rigid standards of judging dates and had higher expectations in terms of socially desired characteristics. Men had higher aspirations than females only in the area of physical attractiveness. Bell (1962) reported that few coeds saw the purpose of a college education as primarily providing an education, rather, they saw it as a side issue, while moving towards marriage.

A question of interest to educators in the 1970 's is whether students today use a prestige rating system in their dating and mate selection process, or whether they select on the basis of personality. High school and college courses in Marriage and the Family usually cover the topic of dating and mate selection as a unit of study. It is 


\begin{tabular}{|c|c|c|}
\hline & Number & Percent \\
\hline TOTAL NUMBER OF RESPONDENTS & 354 & \\
\hline $\begin{array}{l}\text { RACE } \\
\text { Black } \\
\text { White }\end{array}$ & $\begin{array}{l}123 \\
221\end{array}$ & $\begin{array}{l}37.6 \\
62.4\end{array}$ \\
\hline $\begin{array}{l}\text { AGE OF FIRST DATE } \\
12 \text { years of age } \\
13 \text { years of age } \\
14 \text { years of age } \\
15 \text { years of age } \\
16,17 \text {, and } 18 \text { years of age } \\
\text { Have never dated }\end{array}$ & $\begin{array}{r}35 \\
57 \\
90 \\
101 \\
50 \\
19\end{array}$ & $\begin{array}{r}9.9 \\
16.2 \\
25.6 \\
28.7 \\
14.2 \\
5.4\end{array}$ \\
\hline $\begin{array}{l}\text { PRESENT DATING BEHAVIOR } \\
\text { Do not date } \\
\text { Alrnost never date } \\
\text { Random-date } \\
\text { Date two or three people } \\
\text { Date just one person, but not steadily. } \\
\text { Steady date } \\
\text { Engaged and married }\end{array}$ & $\begin{array}{l}39 \\
45 \\
72 \\
55 \\
34 \\
94 \\
12\end{array}$ & $\begin{array}{r}11.1 \\
12.8 \\
23.8 \\
12.4 \\
9.7 \\
26.8 \\
3.4\end{array}$ \\
\hline $\begin{array}{l}\text { FREQUENCY OF DATING } \\
\text { Do not date } \\
\text { Date occasionally } \\
\text { One date a week } \\
\text { Two-three dates a week } \\
\text { Three or more dates a week }\end{array}$ & $\begin{array}{r}43 \\
127 \\
72 \\
71 \\
39\end{array}$ & $\begin{array}{l}12.2^{\star} \\
36.1 \\
20.5 \\
20.2 \\
11.1\end{array}$ \\
\hline $\begin{array}{l}\text { DESIRE TO DATE } \\
\text { Do not want to date } \\
\text { Date occasionally } \\
\text { Once a week } \\
\text { Two-three times a week } \\
\text { Three or more times a week }\end{array}$ & $\begin{array}{r}11 \\
93 \\
82 \\
103 \\
55\end{array}$ & $\begin{array}{r}3.2 \\
27.0 \\
23.8 \\
29.9 \\
16.0\end{array}$ \\
\hline
\end{tabular}

*The discrepancy between the present dating behavior and frequency of dating was caused by the fact that married students checked the "Do not Date" category in the latter instance.

common for discussions to revolve around the topic of what is important to consider in selecting a date or future mate. Previous research has done little to enlighten educators concerning differences that may exist in dating-mating cholces based on race of an individual and the socio-cultural influences to which he has been exposed. This paper presents at least a partial answer to the former question as well as looking at racial and socio-cultural differences.

The participants for this study were 354 high school students between the ages of 15 and 19. (A detailed discussion of the theory, methodology, findings, and conclusions can be found in the author's dissertation.) The sample was evenly distributed between males and females, and the racial distribution was reflective of the racial distribution in the public high schools of the locale $(62.4 \%$ white and $37.6 \%$ black). Table 1 provides information about the respondents' dating behavior. Only a small percentage of the sample did not date or did not want to date. Approximately one-fourth of the sample steady-dated, and another one-fourth random dated. The frequency of dating indicated that slightly over une-third of the students dated only occasionally.

Respondents were asked to choose twelve items out of a total of thirty-three items on a Dating-Rating checklist in each of three columns. In the first column, the students were asked to check those characteristics they perceived as important to their peers in determining popularity as a date.' In the

' Referred to in the study as "perceived level of popularity." 
Table 2.

Rank Order Choices on the Dating-rating Checklist

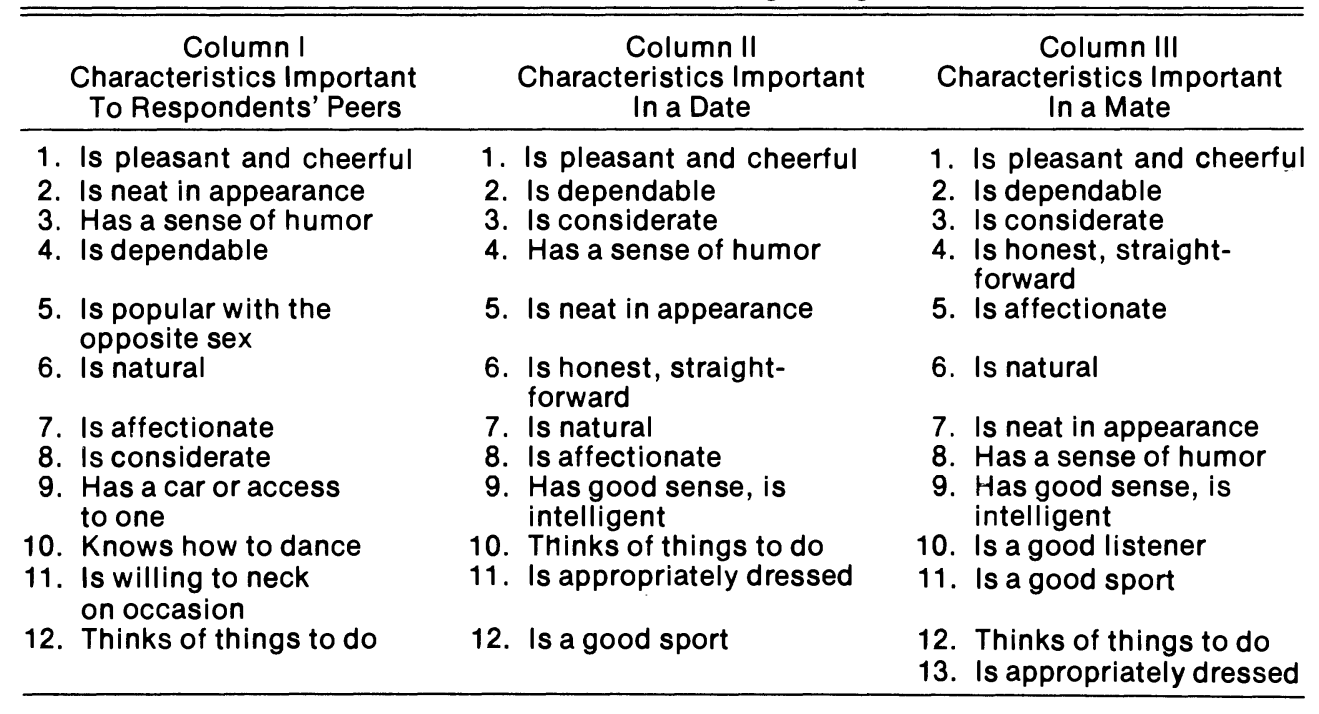

second column, students were to choose characteristics important to them personally in a date; ${ }^{2}$ and in the third column, they were to choose characteristics important to them in a future mate. ${ }^{3}$ Table 2 indicates the first twelve rank order cholces of the respondents in each of the columns.

\section{What Students Think is Important in a Date and Future Mate}

The four characteristics chosen by the students as important to their peers that do not appear in the list of characteristics important in a date or future mate are:

"Is popular with the opposite sex"

"Has a car or access to one"

"Knows how to dance"

"Is willing to neck on occasion"

All of these characteristics are based on an external or prestige rating system, rather than on internal or personality characteristics of an individual. The external traits are those which are readily observable by others or denote materialistic or monetary worth of an Individual. Internal traits may not be as readily observable to others, and often are characteristics pertaining to an individual's personality or self. In the columns where students were asked to choose characteris-

\footnotetext{
'Referred to In the study as "dating level."

"Referred to in the study as "mate selection level."
}

tics important to them in a date or future mate, their choices were all of an internal or personality nature, with two exceptions: "Is appropriately dressed" and "Is neat in appearance." It is interesting that these two characteristics involved external appearance of a person. How an individual dresses, standards of cleanliness, and grooming are obviously important to young people. A person's appearance is readily observable, but on a deeper level, may also be indicative of how a person feels about himself.

Differences were found between males and females in their choices of characteristics. Males at the perceived level of popularity, chose characteristics of an external or prestige nature; whereas females chose personality characteristics with the exception of the importance they placed on car ownership. At the dating level there were no significant differences in choices made by males and females. At the mate selection level, however, females had very definite choices of what they wanted in a future mate (all based on personality); whereas males had no significant choices of characteristics important to them in a future mate.

Black students, in contrast to white students, chose characteristics of an external nature both at the perceived level of popularity and also at the dating level, as reflected in Table 3 . White students had 
Table 3.

Choices on the Dating-Rating Checklist Classified by Race

\begin{tabular}{|c|c|c|c|c|c|}
\hline \multicolumn{2}{|c|}{$\begin{array}{l}\text { Perceived Level } \\
\text { of Popularity' }\end{array}$} & \multicolumn{2}{|c|}{ Dating Level ${ }^{2}$} & \multicolumn{2}{|c|}{ Mate Selection Level ${ }^{3}$} \\
\hline Black & White & Black & White & Black* & White \\
\hline $\begin{array}{l}\text { Has a car or } \\
\text { access to one }\end{array}$ & $\begin{array}{l}\text { Is pleasant } \\
\text { and cheerful }\end{array}$ & $\begin{array}{l}\text { Appropriately } \\
\text { dressed }\end{array}$ & $\begin{array}{l}\text { Pleasant and } \\
\text { cheerful }\end{array}$ & & $\begin{array}{l}\text { Pleasant and } \\
\text { cheerful }\end{array}$ \\
\hline \multirow[t]{10}{*}{$\begin{array}{l}\text { Knows how to } \\
\text { dance }\end{array}$} & $\begin{array}{l}\text { Has a sense } \\
\text { of humor }\end{array}$ & & Dependable & & Dependable \\
\hline & Is dependable & & Considerate & & Considerate \\
\hline & Is natural & & $\begin{array}{l}\text { Sense of } \\
\text { humor }\end{array}$ & & $\begin{array}{l}\text { Honest and } \\
\text { straight- } \\
\text { forward }\end{array}$ \\
\hline & Is affectionate & & $\begin{array}{l}\text { Honest and } \\
\text { straight- } \\
\text { forward }\end{array}$ & & Affectionate \\
\hline & Is considerate & & Natural & & Natural \\
\hline & & & Good sport & & Good sport \\
\hline & & & & & $\begin{array}{l}\text { Good sense, is } \\
\text { intelligent }\end{array}$ \\
\hline & & & & & $\begin{array}{l}\text { Wrote in their } \\
\text { own character- } \\
\text { istic: }\end{array}$ \\
\hline & & & & & $\begin{array}{l}\text { "Same reli- } \\
\text { gion" }\end{array}$ \\
\hline & & & & & "Mature" \\
\hline
\end{tabular}

"No choices were made that were statistically significant at the .05 level.

' Characteristics important to respondents' peers.

${ }^{2}$ Characteristics important in a date.

${ }^{3}$ Characteristics important in a mate.

definite choices of what they valued at all three of the levels, all of which reflected internal or personality choices. It should be noted that more of the black students in the sample were from families of a lower socio-economic level than were the white students. More than half of the black students came from homes where the father was semi-skilled, unskilled or unemployed; whereas only $14 \%$ of the white students' fathers were semi-skilled, unskillêd or unemployed. Indeed, the differences between black and white students may, in reality, reflect socio-economic class differences.

\section{Discussion}

Perceived popularity based on external characteristics. The results indicated that students at the perceived norm level of what constitutes popularity, in general, made more choices of characteristics that were external or of a prestige nature than at the dating and future mate selection levels. An interesting question for discussion with a student population would be, "Why do students perceive their peers as choosing external values, yet choose internal characteristics for themselves?" One might wonder whether students perceived that their peers have certain expectations, but never have an opportunity to explore if, in fact, that is what exists. Educators might use this difference in perception and reality to explore students' stereotypes, cultural norms, attitudes of others, and self-attitudes when choosing a date and future mate.

An individual perceives his dating choices as more serious than that of others. Young people at the perceived norm level may view dating as recreational and fun, and therefore, choose items such as having a car and knowing how to dance, which reflect those values. Two choices at the perceived norm level, "popularity with the opposite sex" and "willingness to neck on occasion" may reflect some feelings that students hold at an 
emotional level rather than a cognitive level. When the choices of characteristics were based on what a student personally would like in a date, they may well have been made on a cognitive or more rational level. Dating as a form of behavior may be viewed as a more serious relationship at a personal level of choice rather than recreational or fun as it may be viewed at a level of perception.

Emotional and rational choices may differ. A list of characteristics is limited in its comparability to a real life situation in which emotion and other factors can influence rational choices of a date or future mate. It would certainly be easier to logically choose from a list of characteristics important in a date in the classroom environment than it would be in the back seat of a car. While differences that may occur between emotional choices and rational choices are often divergent, a list of desired characteristics can serve as a springboard for discussion of values in terms of mate selection.

The white, Protestant middle-class ethic is not reflected by dating choices of black students. An interesting dimension for exploration is the effect of the white, middle-class, Protestant ethic that was reflected in white students' choices of characteristics such as pleasantness, dependability and consideration. White students, in general, placed more value on internal or personality characteristics of an individual; whereas black students placed more value on external characteristics. Explanations for the difference between black and white students' choices may be based on the lower socio-economic level of the black students as well as on differences in communication patterns that might exist in white and black families (especially between lower-class black families and middle to upper-middle class white families).

Gender and race differences do exist in choosing a date and mate. Parental and societal values appear to influence choices of adolescents. Hudson and Henze (1969) studied the value system of the college population of the 1960's and found that youth value the importance of personal characteristics in mate selection in much the same way as they did a generation ago. A person's environment and self-identity, as well as the values he assimilates all appear to influence his choices of characteristics important in a date and future mate. Educators need to reevaluate what students value in dating and mate selection. This is necessary in light of social changes in society. The black-white and male-female differences in choices of what is valued in a date and future mate indicate a need to be aware of differences based on gender and race.

\section{Implications}

Future research on dating and mate selection may take on new perspectives as masculine and feminine roles in our society continue to change. Both sexes appear to be increasingly more egalitarian in the past few years. Will this more egalitarian view of roles provide a person-centered approach to dating and mate selection rather than a genderoriented one? Or will women tend to increase at a substantially greater rate in the direction of an egalitarian relationship, thus continuing to create a gender difference in choices of characteristics?

Geographic location may be a determiner of attitudes toward dating and mate selection. This study was conducted in the South in a city of approximately 80,000 . The city is conservative and although urban and a state capital, has retained many characteristics of a more rural area. Regional variations, as well as urban-rural differences might well be factors that should be compared in future research. Does a female from a rural town in the South, choose the same characteristics in a date and mate as a female from an urban area on the West coast?

This research tends to reveal the need for using classroom discussion with high school youth on the topic of dating and mate selection. Attitudes, beliefs and values on dating and mate selection are different for each individual. A student's gender, race, socio-cultural environment and geographic location all may influence how he views the topic.

\section{REFERENCES}

Bell, R. R. Some factors related to coed marital aspirations. Family Life Coordinator, 1962, 11, 91-94. 
Blood, R. O. A retest of Waller's rating complex. In M. Sussman (Ed.), Sourcebook in marrlage and the famlly (2nd od.). Boston: Houghton Mifflln, 1963.

Coombs, R. H., \& Kenkel, W. F. Sex differences in dating aspirations and satisfaction with computer-selected partners. Journal of Marriage and the Famlly, 1866, 28, 62-66.

Hudson, J. W., \& Henze, L. F. Campus values in mate selection: A replication, Journai of Marriage and the Family, 1969, 31, 772-775.

Skipper, J. K., \& Nass, G. Dating behavlor: A framework for analysis and an illustration. Journal of Marriage and the Family, 1966, 30, 412-420.

Smith, W. M. Rating and dating: A re-study. Marriage and Family Living, 1952, 14, 312-317.

Waller, W. The rating and dating complex. American Socioiogicai Review, 1937, 2, 727-734.

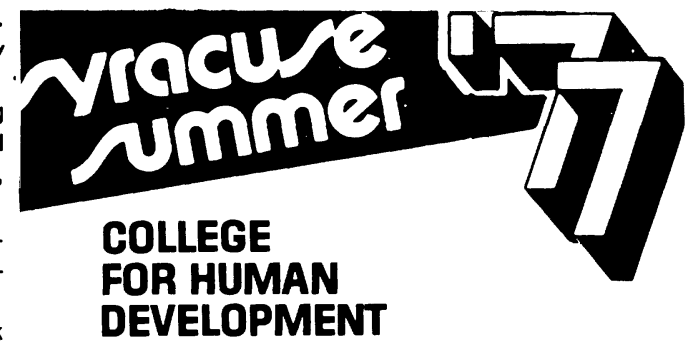

WORKSHOPS AND STUDY SEMINARS

FIRST SESSION-MAY 23-JULY 1.

- Introduction to Textiles.

- Language Development in Children.

- Workshop in Sewing Machine as a Creative Tool.

- Training Care-Givers of Children Under Three.

- Seminar in Clinical Nutrition.

\section{SECOND SESSION-JULY 6-AUGUST 12}

- Creative Activities for Young ChildrenJuly 7 -July 29.

- PRIORITY ONE: WORKSHOP ON PARENT SEX EDUCATION-JULY 6-JULY 15.

(Limited en rollment-Permission of Instructor.)

FOR MORE INFORMATION WRITE:

COLLEGE FOR HUMAN DEVELOPMENT

200 SLOCUM HALL • SYRACUSE, N.Y. 13210

\section{SYRACUSE UNIVERSITY}


http://www.jstor.org

\title{
LINKED CITATIONS \\ - Page 1 of 1 -
}

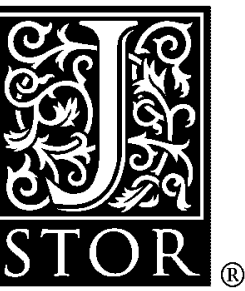

You have printed the following article:

\section{Dating Choices of High School Students}

Sally L. Hansen

The Family Coordinator, Vol. 26, No. 2. (Apr., 1977), pp. 133-138.

Stable URL:

http://links.jstor.org/sici?sici=0014-7214\%28197704\%2926\%3A2\%3C133\%3ADCOHSS\%3E2.0.CO\%3B2-P

This article references the following linked citations. If you are trying to access articles from an off-campus location, you may be required to first logon via your library web site to access JSTOR. Please visit your library's website or contact a librarian to learn about options for remote access to JSTOR.

\section{References}

\author{
Some Factors Related to Coed Marital Aspirations \\ Robert R. Bell \\ The Family Life Coordinator, Vol. 11, No. 4. (Oct., 1962), pp. 91-94. \\ Stable URL: \\ http://links.jstor.org/sici?sici=0886-0394\%28196210\%2911\%3A4\%3C91\%3ASFRTCM\%3E2.0.CO\%3B2-M
}

